\title{
肥満症 /メタボリックシンドロームの概念
}

大阪大学大学院内分泌・代謝内科学

中村 正

近年、過食や運動不足などの生活習慣の変化により、肥満人口が急増し、糖尿病、高血圧、脂質代謝異 常などのいわゆる生活習慣病が増加している。日本人は欧米人に比べ軽度の肥満でもこれら疾病が合併し やすい特徴を持っている。よって、2000 年に日本肥満学会はBMI 25 以上を肥満と判定し、肥満に関連し 減量により改善する健康障害を持つものを肥満症と定義した。なかでも、腹腔内内臓脂肪蓄積を基盤とす る、脂肪細胞の機能異常に基づく肥満症が心血管疾患の成因として重要であり、この病像がさらに一歩進 展したものとしてメタボリックシンドロームの概念が存在する。2005 年に発表されたわが国のメタボリッ クシンドロームの診断基準では、内臓脂肪蓄積が主要必須項目となっている。内臓脂肪蓄積の評価基準と して、腹囲測定が用いられ、男性 $85 \mathrm{~cm}$ 以上、女性 $90 \mathrm{~cm}$ 以上が腹部肥満と診断される。これは、内臓脂肪 量評価の標準である臍レベル CT 断面像での内臟脂肪面積 $100 \mathrm{~cm}^{2}$ に対応する数值である。内臟脂肪蓄積に 加えて、高トリグリセリド血症かつ／または低 HDL コレステロール血症、高血圧、空腹時高血糖の 3 項目 のうち 2 項目以上あればメタボリックシンドロームと診断する。

健診時の総合判定では、これまで、一つ一つの項目に対し、その異常の程度を考慮してコメントされて いたが、メタボリックシンドロームの場合は根本的に異なる。すなわち、各項目の異常の軽重にかかわら ず、リスクが複合することが問題であることを明確に伝える必要がある。実際に、メタボリックシンドロ ームと診断された場合、この状態が狭心症や心筋梗塞と言った心血管障害を高率に起こしてくるため危険 であること、リスクの集積が起こると単一リスクがある場合に比べ著しく危険率が増加することを理解し てもらうことが大切である。現在、腹囲測定はまだまだ一般的ではないが、肥満症における内臟脂肪推定 やメタボリックシンドロームの診断には必ず必要であり手技も簡単なことから、健康診断の場に積極的に 取り入れる必要がある。最近、私たちは腹部インピーダンス法を用いた内臓脂肪測定装置を開発中であり その概要も紹介する。 